\title{
POVEZANOST OBILJEŽJA PRIVATNIH ŠUMOPOSJEDNIKA S RAZINOM NJIHOVE AKTIVNOSTI U OKRUPNJAVANJU ŠUMOPOSJEDA
}

\section{CHARACTERISTICS OF PRIVATE FOREST OWNERS IN RELATION TO THEIR ACTIVITIES IN ENLARGEMENT OF FOREST HOLDINGS}

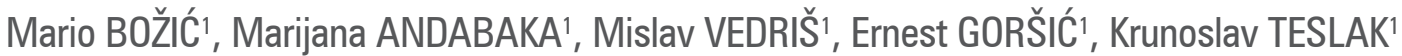

\begin{abstract}
SAŽETAK
Većina privatnih šumoposjednika u Hrvatskoj ima šumoposjed manji od 1 ha, što predstavlja značajan ograničavajući čimbenik u gospodarenju šumama. Cilj ovoga rada je ispitati povezanost sociodemografskih značajki šumoposjednika i obilježja šumoposjeda s razinom zainteresiranosti šumoposjednika za kupnju, zamjenu ili prodaju čestica pod šumom, u svrhu okrupnjavanja i povećanja suvislosti posjeda. Neposrednim anketiranjem ispitano je 500 šumoposjednika na području kontinentalne Hrvatske. Za dobivene podatke napravljena je statistička deskriptivna obrada, te izračunate mjere korelacije i testiranje razlika pojedinih kategorija. Rezultati ukazuju na jasnu povezanost sociodemografski, regionalnih i drugih obilježja šumoposjednika s razinom zainteresiranosti za okrupnjavanje šumoposjeda. Tipičan šumoposjednik zainteresiran za povećanje šumoposjeda je muškarac mlađi od 50 godina, sa završenom srednjom školom ili fakultetom, iz središnje Hrvatske koji je svoj posjed stekao kupnjom i već je aktivan bilo u udrugama šumoposjednika, bilo da koristi savjetodavne usluge Ministarstva poljoprivrede. Premali udio šumoposjednika zainteresiranih za prodaju šumoposjeda $(18,9 \%)$ onemogućava daljnje okrupnjavanje. Prema tomu, mjere regulatora treba usmjeriti na proces nasljeđivanja, oprezivanje negospodarenja šumoposjedom i daljnje subvencioniranje aktivnog i disperziranog gospodarenja šumama (biomasa, nedrvni šumski proizvodi, općekorisne funkcije šuma, naknade za pohranu ugljika, naknade za ciljane vrste).
\end{abstract}

KLJUČNE RIJEČI: privatne šume, kupnja šuma, prodaja šuma, okrupnjavanje šumoposjeda, gospodarenje šumama

\section{UVOD}

\section{INTRODUCTION}

Površina šuma privatnih šumoposjednika u Republici Hrvatskoj (RH), prema šumskogospodarskoj osnovi područja iz 2016 godine (ŠGOP, 2016) iznosi 661.720,89 ha ili $24 \%$ ukupne površine šuma RH. Udjelom od gotovo četvrtine ukupne površine predstavljaju značajan, ali trenutno nedo- voljno iskorišteni prirodan resurs. Zakon o šumama (NN 68/2018), šumoposjednike prema površini šume i šumskog zemljišta dijeli na: male (do 20 ha), srednje (više od 20, a manje od 300 ha) te velike (više od 300 ha). Prema podacima Ministarstva poljoprivrede, privatni šumoposjed veličine do 1 ha („sitni“) ima čak 85,15\% šumoposjednika $(37,80 \%$ površine privatnih šuma), a svega $0,28 \%$ posjed veći od 10 ha (13,64\% površine privatnih šuma).

\footnotetext{
'prof. dr. sc. Mario Božić, dr.sc. Marijana Andabaka, izv.prof.dr.sc. Mislav Vedriš, doc.dr.sc. Ernest Goršić, izv.prof.dr.sc. Krunoslav Teslak; Sveučilište u Zagrebu, Fakultet šmarstva i drvne tehnologije, Zavod za izmjeru i uređivanje šuma

*dopisni autor: Mislav Vedriš, mvedris@sumfak.hr
} 
U Hrvatskoj su obilježja privatnih šumoposjednika istraživana u nekoliko studija (Čavlović, 2004; Paladinić i dr., 2008; Posavec i dr., 2011, Teslaki dr., 2018). Prema tim istraživanjima tipičan „sitni“ privatni šumoposjednik je osoba starije dobi, najčešće umirovljenik ili poljoprivrednik, koji svoj sitni posjed ne može niti želi povećati kupnjom šume, ali isto tako niti ga prodati. Šumu želi zadržati kao neko posebno dobro, iako ona nema za njega gospodarskog značenja. Novije studije (npr. Teslak i dr., 2018; Žunić i Teslak, 2019) bilježe blago povećanje udjela mlađih, obrazovanijih šumoposjednika te pojavu krupnijih privatnih šumoposjeda, no u ukupnom broju još uvijek predstavljaju neznatan udio.

Veličina šumoposjeda odlučujući je čimbenik za gospodarenje šumom, a također je vrlo povezana sa stavovima šumoposjednika, što je vidljivo u istraživanju Butlera i dr. (2021). Ograničenja u gospodarenju šumama koja proizlaze iz veličine šumoposjeda prepoznata su u istraživanjima Schurra (2006), Suuriniemija i dr. (2012), a u Hrvatskoj u objavama Posavca i dr. (2011), Posavca i Beljana (2012), Berte i dr. (2017), te Teslaka i dr. (2018). Usitnjeni, a usto i rascjepkani privatni šumoposjedi u Hrvatskoj, ne otvaraju mogućnosti za razvoj gospodarenja u šumama privatnih šumoposjednika (Božić i dr., 2011). Jasno je da su mogućnosti i očekivanja od bavljenja šumarstvom značajno različita između šumoposjednika s posjedom veličine od 1 ha i onoga s posjedom od 100 ili više ha, a održivo gospodarenje moguće je jedino na većim šumoposjedima (Glück i dr., 2010). Minimalna površina šume za samostalno funkcioniranje šumoposjeda trebala bi iznositi okvirno 5-20 ha, pri čemu je 5 ha minimum za samoopskrbu ogrjevnim drvom, a 10 i više ha je potrebno u svrhu multifunkcionalnog, ali primarno na drvo orijentiranog gospodarenja (Schurr, 2006). Ozbiljno bavljenje šumarstvom ne može se očekivati od šumoposjednika koji imaju posjed manji od 20 ha (Pelzzman i Čavlović, 2003).

Povećanjem ukupne površine šuma privatnih šumoposjednika u Hrvatskoj uz povećanu potražnju za drvnim proizvodima povećava se i značajnost privatnog šumarstva u zajednici (Teslak i dr., 2018.). Daljnji razvoj povećanja proizvodnje drvnih i nedrvnih proizvoda šuma, ali i stabilnosti šumskih ekosustava privatnih šuma opterećen je porastom ograničenja u gospodarenju proizašlih iz porasta površina u nekom obliku stroge zaštite. Daljnja ograničenja mogu se očekivati uslijed zahtjeva za smanjenjem emisija ugljika, ograničavanju količine sječa i destimuliranja uporabe drva za ogrjev. Često sami šumoposjednici smatraju da negospodarenjem doprinose zaštiti prirode (Ficko i Bončina 2015, Žunići Teslak 2019) što je posebno izraženo za šumoposjednike koji su posjed naslijedili, žive u gradu i materijalno su osigurani. Na postojeća i buduća ograničenja i izazove u gospodarenju šumama otporniji će biti po- vršinom veći šumoposjedi i posjedu posvećeniji šumoposjednici.

Stoga je cilj ovog istraživanja ispitati zainteresiranost šumoposjednika za kupnju, zamjenu ili prodaju svojih čestica pod šumom, u svrhu okrupnjavanja i povećanja kompaktnosti posjeda, te analiza utjecaja sociodemografskih značajki šumoposjednika i obilježja šumoposjeda na tu zainteresiranost.

\section{MATERIJAL I METODE MATERIAL AND METHODS}

\section{Anketiranje šumoposjednika - Survey of forest owners}

Za uspješnost reguliranja i provedbe svih promjena vezanih za privatne šume ključno je istražiti razmišljanja samih šumoposjednika. $U$ tu svrhu provedeno je anketiranje šumoposjednika putem anketnih upitnika o sociodemografskim karakteristikama šumoposjednika, obilježjima šumoposjeda te zainteresiranosti šumoposjednika za kupnju (K), zamjenu $(Z)$ i prodaju $(P)$ čestica pod šumom.

S obzirom na nerazvijeno tržište prodaje zemljišta (čestica) pod šumom (Posavec i dr., 2006) , upitno je koliko će oni koji bi htjeli kupnjom povećati svoj posjed biti u prilici kupiti susjedne šumske čestice. Stoga je u upitniku kupnja razlučena na dvije potkategorije: zainteresiranost za kupnju susjednih čestica (Kupnja) te za kupnju čestica koje se ne naslanjaju na njihov trenutni šumoposjed (Kupnja 2), u svrhu povećanja posjeda ili postizanja kompaktnosti naknadnom kupnjom ili zamjenom čestica.

Istraživanje je provedeno kao neposredno anketiranje uz pomoć zaposlenika Hrvatske poljoprivredno-šumarske savjetodavne službe na područjima sa (većinom) značajnijim udjelima privatnih šuma (Krajter Ostoići dr., 2015). Anketa je provedena tijekom proljeća 2018. godine, među šumoposjednicima za koje su anketari imali saznanja da posjeduju šumu, a bili su voljni ispuniti anketu. Ukupno je anketirano 500 privatnih šumoposjednika, a konačnu bazu za statističke analize čini 487 ispitanika, jer su provjerom ispunjenih anketa u nekima (13) uočeni značajniji propusti pri ispunjavanju, te su izuzete iz daljnje obrade. S obzirom na veličinu uzorka te pretpostavke da su prikupljeni uzorci reprezentativni u odnosu na stvarnu populaciju privatnih šumoposjednika, rezultati se mogu smatrati relevantnima i odražavaju zainteresiranost privatnih šumoposjednika u Republici Hrvatskoj za kupnju, prodaju i zamjenu šumoposjeda.

Anketirani šumoposjednici upoznati su sa svrhom ankete te su odgovarali na opća pitanja i pitanja o zainteresiranosti za aktivnosti radi okrupnjavanja šumoposjeda (kupnja, zamjena, prodaja). Opća pitanja odnose se na obilježja sa- 
mih ispitanika (spol, dob, stručna sprema i socijalni status), obilježja šumoposjeda (lokacija šumoposjeda, površina šumoposjeda) te na pokazatelje uključenosti u gospodarenje šumoposjedom (način stjecanja šumoposjeda, stupanj zainteresiranosti za gospodarenje, članstvo u udrugama šumoposjednika, upis u Upisnik šumoposjednika te koriste li se uslugama šumarske Savjetodavne službe). Zainteresiranost za provođenje aktivnosti je iskazana ocjenom 1-5, pri čemu ocjena 1 predstavlja potpunu nezainteresiranost, a ocjena 5 najveću zainteresiranost.

Dob je prikupljena kao kontinuirano obilježje, ali je za potrebe obrade podataka svrstana u tri kategorije: [20-50), [50$70)$ te $[70+)$ godina, a površina šumoposjeda u pet kategorija: $<1$ ha, [1-5), [5-20), [20-50) te [50+) hektara. Na temelju načina na koji su stekli šumoposjed, šumoposjednici su svrstani u tri kategorije: nasljeđivanjem, kupnjom šuma nakon demokratskih promjena u RH, kada se na vlasništvo prestalo negativno gledati (kupnjom) te povratom šuma oduzetih za vrijeme komunističke vladavine (povratom).

Istraživanja je obuhvatilo šumoposjede na području sljedećih županija: Zagrebačke (ZŽ), Sisačko-moslavačke (SMŽ), Varaždinske (VŽ), Bjelovarsko-bilogorske (BBŽ), Primorsko-goranske (PGŽ) i Međimurske (MŽ).

\section{Obrada podataka - Data analysis}

Na temelju podataka o obilježjima šumoposjeda i šumoposjednika iz anketnih listića formirana je baza podataka. Provedena je njihova analiza i provjera te ispravak krivo unesenih, nerealnih i nelogičnih podataka. Obrada podataka provedena je u programskom paketu MS Excel te programskom paketu Statistica 13.3 (TIBCO Software Inc., 2018).

U ovom radu analizirana je zainteresiranost šumoposjednika za okrupnjavanje šumoposjeda kroz sljedeće aktivnosti (varijable iz upitnika):

- kupnja susjednih čestica (Kupnja)

- kupnja čestica koje nisu susjedne (Kupnja 2)

- zamjena čestica (Zamjena)

- prodaja čestica (Prodaja)

Za navedene varijable izračunate su aritmetička sredina i medijan. Usporedba ocjena između kategorija je zbog nehomogenosti varijanci provedena Mann-Whitneyjevim, odnosno Kruskal-Wallisovim testom (za usporedbu više od dviju kategorija).

Povezanost varijabli iskazana je Spearmanovom korelacijom rangova. Kod svih analiza zadana je razina značajnosti 0,05 .

Radi jasnijeg prikaza rezultata za dio analiza ocjena zainteresiranosti za kupnju, prodaju i zamjenu prevedena je u tri kategorije: Jako zainteresirani - ocjene 4 i 5 (oznaka +), srednje zainteresirani - ocjena 3 (oznaka \pm ) te nezainteresirani - ocjene 1 i 2 (oznaka-).

\section{REZULTATI ISTRAŽIVANJA RESULTS}

Među ispitanicima prevladavaju muškarci $(80,3 \%$ svih ispitanika), starije osobe (iznad 50 godina je gotovo $70 \%$ ispitanika) te ispitanici sa srednjom stručnom spremom (58,2\%). Zaposlenih je približno 50\%, a umirovljenika $40 \%$. Najveći je udio ispitanika iz Primorsko -goranske županije $(31,7 \%)$. Gotovo polovica ispitanika posjeduje šumu veličine 1- 5 ha, dok je 32,2\% ispitanika sa šumoposjedom manjim od 1 ha (tablica 1$)$.

Većina ispitanika (tablica 2) posjed je stekla nasljeđivanjem (76,2\%), srednje su zainteresirani za gospodarenje (51,3\%), nisu članovi udruga šumoposjednika (86,9\%), niti su upisani u Upisnik $(73,1 \%)$, ali koriste usluge šumarske savjetodavne službe $(58,1 \%)$.

Za kupnju susjednih čestica (Kupnja) više su zainteresirani muškarci, mlađi šumoposjednici, više stručne spreme, koji su samozaposleni ili nezaposleni, imaju posjed na području Bjelovarsko-Bilogorske ili Sisačko-Moslavačke županije te imaju veći šumoposjed (tablica 1), odnosno šumoposjednici koji su posjed stekli kupnjom, iskazuju jaku zainteresiranost za gospodarenje svojim šumoposjedom, članovi su neke od udruga šumoposjednika, upisani su u Upisnik šumoposjednika te koriste usluge Šumarske savjetodavne službe (tablica 2).

Zainteresiranost za kupnju čestica koje nisu susjedne (Kupnja 2) očekivano je nešto niža u odnosu na kupnju susjednih čestica (Kupnja), ali postoji visok stupanj korelacije između ove dvije aktivnosti $(0,82)$.

Zainteresiranost za zamjenu čestica (Zamjena) je nešto niža u odnosu na zainteresiranost za kupnju susjednih čestica. Za zamjenu su zainteresiraniji mlađi šumoposjednici, više stručne spreme koji imaju šumoposjed na području Bjelovarsko-Bilogorske i Primorsko-goranske županije, koji imaju šumoposjede veličine [20-50) ha (tablica 1) te koji su posjed stekli povratom ili kupnjom, jako su zainteresirani za gospodarenje šumom, članovi su udruga šumoposjednika te su upisani u Upisnik (tablica 2).

Za prodaju šumoposjeda (Prodaja) zainteresiranije su žene, šumoposjednici stariji od 70 godina, umirovljenici, šumoposjednici koji imaju posjed u Sisačko-Moslavačkoj i Primorsko-goranskoj županiji (tablica 1), koji su posjed stekli povratom te koji nisu zainteresirani za gospodarenje šumom (tablica 2). Međutim svakako valja uočiti da je prosječna zainteresiranost za prodaju puno manja nego za kupnju. Ispitanika koji su jako zainteresirani za kupnju ima $35,2 \%$ u ukupnom uzorku, a jako zainteresiranih za prodaju svega $18,9 \%$.

Povećanje površine šumoposjeda moguće je samo ako u isto vrijeme s jedne strane imamo one koji su spremni kupiti, a s druge strane one koji bi svoj šumoposjed bili spre- 


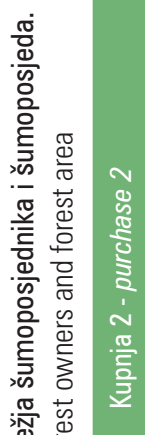

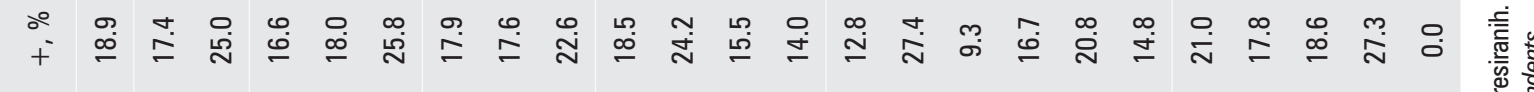

$$
\begin{aligned}
& \stackrel{\Re}{\infty}
\end{aligned}
$$

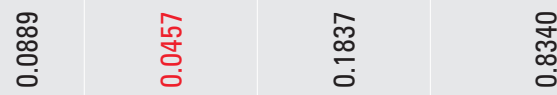

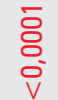

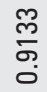

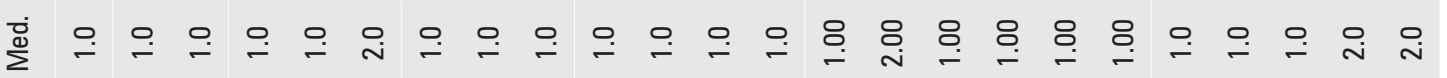

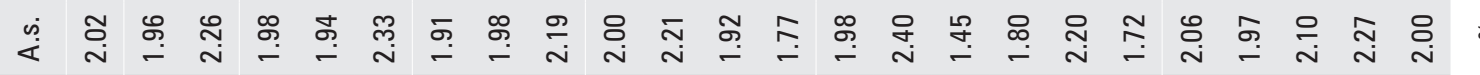

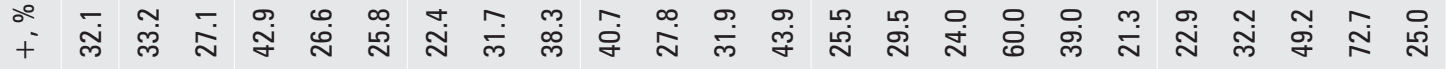

$$
\begin{aligned}
& \text { 呙 }
\end{aligned}
$$

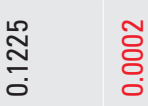

$$
\begin{aligned}
& \text { 兽 } \\
& \sigma \text { ○ } \\
& \stackrel{\substack{0 \\
0}}{\circ} \\
& \text { চे }
\end{aligned}
$$
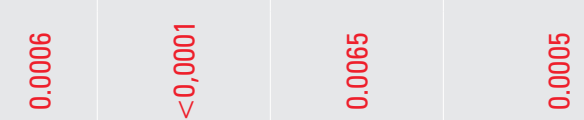

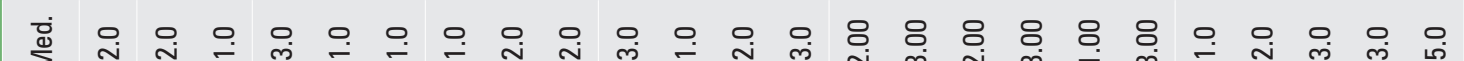

$$
\text { ต }
$$

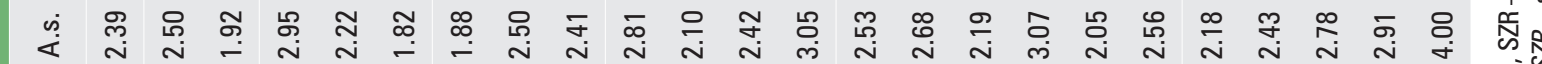

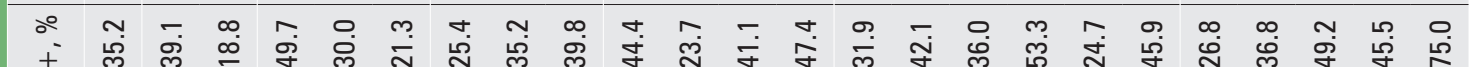

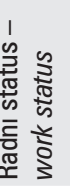



怘

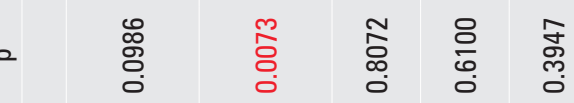

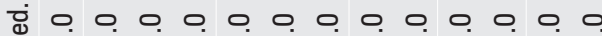
주용요 $4-4-4-44-444-4$

mni prodati. Niska, pozitivna i statistički neznačajna korelacija između kupnje i prodaje $(0,07)$ razlog što su načinjene dodatne analize u kojima će se promotriti kombinacije zainteresiranosti pojedinih šumoposjednika za kupnju, prodaju i zamjenu. Rezultati tih analiza prikazani su na slici 1 i tablicama 3 i 4.

Iz slike 1 vidi se da čak 168 ispitanika (34,5\% svih ispitanih) nije zainteresirano niti za kupnju niti za prodaju šumoposjeda, pri čemu njih $81,5 \%$ (od tih 168) nije zainteresirano niti za zamjenu. Pitanje je da li ispitanike koji iskazuju jaku zainteresiranost i za kupnju i za prodaju (njih 40) možemo promatrati kao one koji bi željeli povećati svoj šumoposjed, posebno ako uzmemo u obzir da je njih čak $72,5 \%$ jako zainteresirano i za zamjenu čestica. Očekivani odgovor, da su jako zainteresirani za kupnju, a nezainteresirani za prodaju odnosno obratno dalo je 115 odnosno 34 ispitanika (slika 1). To je ukupno $30,6 \%$ svih ispitanika. Upravo ove dvije kategorije su oni šumoposjednici koji su zanimljivi u postupku povećanja šumoposjeda, te su detaljnije analizirani (tablice 3 i 4).

U ukupnom uzorku muškarci su zastupljeni s 80,3\%, a u uzorku onih koji su jako zainteresirani za kupnju, a nezainteresirani za prodaju šumoposjeda muškaraca je $93 \%$ (tablica 3). Naprotiv, udio žena u ukupnom uzorku iznosi $19,7 \%$, a među nezainteresiranima za kupnju, a jako zainteresiranima za prodaju taj se udio povećava na $36,4 \%$.

Značajnije povećanje udjela pojedinih kategorija među onima koji su jako zainteresirani za kupnju, a nezainteresirani za prodaju u odnosu na ukupni uzorak, također se vidi kod najmlađih ispitanika, više stručne spreme, zaposlenih, šumoposjednika iz Varaždinske županije te šumoposjednika s posjedom 1-50 ha (tablica 3), odnosno šumoposjednika koji su posjed stekli kupnjom, koji su jako zainteresirani za gospodarenje, koji su članovi udruga, 
Tablica 3. Udjeli ispitanika jako zainteresiranih za kupnju a nezainteresiranih za prodaju (Kupnja+ prodaja-) odnosno nezainteresiranih za kupnju a jako zainteresiranih za prodaju šumoposjeda (Kupnjaprodaja+) prema obilježjima šumoposjednika te obilježjima šumoposjeda.

Table 3. Share of respondents very interested in purchase and not interested in selling (Kupnja + prodaja-) and not intersted in purchase and very interested in selling (Kupnja- prodaja +) according to characteristics of forest owners and forest area

\begin{tabular}{|c|c|c|c|c|c|}
\hline & & & $\begin{array}{l}\text { ja }+ \\
\text { aja }-\end{array}$ & & $\begin{array}{l}\text { ja - } \\
\text { aja + }\end{array}$ \\
\hline $\begin{array}{l}\text { Obilježje } \\
\text { - characteristic }\end{array}$ & $\begin{array}{l}\text { Kategorija } \\
\text { - category }\end{array}$ & $\mathrm{n} 1$ & $\mathrm{n} 1 / \mathrm{n}, \%$ & n2 & $\mathrm{n} 2 / \mathrm{n}, \%$ \\
\hline & Svi-all & 115 & 23.6 & 34 & 7.0 \\
\hline & $M$ & 107 & 27.4 & 21 & 5.4 \\
\hline Spol-sex & ž & 8 & 8.3 & 12 & 12.5 \\
\hline & {$[20-50)$} & 55 & 33.7 & 2 & 1.2 \\
\hline Dob-age & {$[50-70)$} & 48 & 20.6 & 17 & 7.3 \\
\hline & {$[70+)$} & 11 & 12.4 & 5 & 16.9 \\
\hline & Niža - low & 9 & 13.4 & 6 & 9.0 \\
\hline $\begin{array}{l}\text { Stručna sprema } \\
\text { - education }\end{array}$ & $\begin{array}{l}\text { Srednja } \\
\text { - secondary }\end{array}$ & 69 & 24.3 & 15 & 5.3 \\
\hline & Viša $+-h i g h$ & 36 & 27.1 & 13 & 9.8 \\
\hline & $\begin{array}{l}\text { Nezaposlen } \\
\text { - unemployed }\end{array}$ & 7 & 25.9 & 0 & 0.0 \\
\hline Radni status & $\begin{array}{l}\text { Umirovljenik } \\
\text { - retired }\end{array}$ & 29 & 14.9 & 23 & 11.9 \\
\hline - work status & $\begin{array}{l}\text { Zaposlen } \\
\text { - employed }\end{array}$ & 58 & 28.0 & 8 & 3.9 \\
\hline & $\begin{array}{l}\text { Samozaposlen } \\
\text { - self-employed }\end{array}$ & 20 & 35.1 & 3 & 5.3 \\
\hline & IZŽ & 8 & 17.0 & 1 & 2.1 \\
\hline & III SMŽ & 23 & 24.2 & 5 & 5.3 \\
\hline Lokacija & V VŽ & 25 & 33.3 & 7 & 9.3 \\
\hline - location & VII BBŽ & 12 & 40.0 & 0 & 0.0 \\
\hline & VIII PGŽ & 23 & 14.9 & 11 & 7.1 \\
\hline & XX MŽ & 22 & 36.1 & 5 & 8.2 \\
\hline & $<1$ ha & 26 & 16.6 & 14 & 8.9 \\
\hline Površina & {$[1-5)$} & 64 & 26.4 & 13 & 5.4 \\
\hline šumoposjeda & {$[5-20)$} & 20 & 35.9 & 5 & 8.5 \\
\hline - forest area & {$[20-50)$} & 4 & 36.4 & 2 & 18.2 \\
\hline & {$[50+)$} & 1 & 25.0 & 0 & 0.0 \\
\hline
\end{tabular}

upisani u Upisnik i koriste usluge Šumarske savjetodavne službe (tablica 4). Značajnije smanjenje udjela zainteresiranih za kupnju uočava se kod najstarijih šumoposjednika, niže stručne spreme, umirovljenika, šumoposjednika iz Primorsko-goranske županije, šumoposjednika s najmanjom površinom šumoposjeda, te onih koji su posjed stekli nasljeđivanjem (tablice 3 i 4 ).

Značajnije povećanje udjela pojedinih kategorija među onima koji su nezainteresirani za kupnju, a jako zainteresirani za prodaju u odnosu na ukupni uzorak, osim kod žena opaža se i kod najstarijih šumoposjednika, šumoposjednika sa višom stručnom spremom, umirovljenika, šu-
Tablica 4. Udjeli ispitanika jako zainteresiranih za kupnju a nezainteresiranih za prodaju, (Kupnja + prodaja-) odnosno nezainteresiranih za kupnju, a jako zainteresiranih za prodaju šumoposjeda (Kupnjaprodaja+) s obzirom na pokazatelje uključenosti u gospodarenje šumoposjedom.

Table 4. Share of respondents very interested in purchase and not interested in selling (Kupnja + prodaja-) and not interested in purchase and very interested in selling (Kupnja- prodaja +) according to activities in forest management

\begin{tabular}{|c|c|c|c|c|c|}
\hline & & & $\begin{array}{l}\text { nja + } \\
\text { daja - }\end{array}$ & & $\begin{array}{l}\text { onja - } \\
\text { laja + }\end{array}$ \\
\hline $\begin{array}{l}\text { Obilježje } \\
\text { - characteristic }\end{array}$ & $\begin{array}{l}\text { Kategorija } \\
\text { - category }\end{array}$ & $\mathrm{n} 1$ & $\mathrm{n} 1 / \mathrm{n}, \%$ & n2 & $\mathrm{n} 2 / \mathrm{n}, \%$ \\
\hline & Svi-all & 115 & 23.6 & 34 & 7.0 \\
\hline & $\begin{array}{l}\text { Nasljeđivanjem } \\
\text { - inheritance }\end{array}$ & 70 & 18.9 & 27 & 7.3 \\
\hline $\begin{array}{l}\text { Posjed ste stekII: } \\
\text { - mean of } \\
\text { acquisition }\end{array}$ & $\begin{array}{l}\text { Kupnjom } \\
\text { - purchase }\end{array}$ & 42 & 44.2 & 3 & 3.2 \\
\hline & $\begin{array}{l}\text { Povratom } \\
\text { - restitution }\end{array}$ & 1 & 7.7 & 2 & 15.4 \\
\hline Zainteresirani za & Jako - very & 77 & 41.2 & 9 & 4.8 \\
\hline $\begin{array}{l}\text { gospodarenje } \\
\text { - interested for }\end{array}$ & $\begin{array}{l}\text { Srednje } \\
\text { - moderate }\end{array}$ & 37 & 14.8 & 14 & 5.6 \\
\hline $\begin{array}{l}\text { forest } \\
\text { management }\end{array}$ & $\begin{array}{l}\text { Nimalo - not } \\
\text { intersted }\end{array}$ & 1 & 2.0 & 11 & 22.0 \\
\hline Član udruge - & $\mathrm{Da}-Y e s$ & 22 & 35.5 & 1 & 1.6 \\
\hline $\begin{array}{l}\text { memeber of } \\
\text { association }\end{array}$ & $\mathrm{Ne}-\mathrm{No}$ & 93 & 22.0 & 32 & 7.6 \\
\hline Upisani u Upisnik & $\mathrm{Da}-\mathrm{Yes}$ & 44 & 36.4 & 4 & 3.3 \\
\hline - registered & $\mathrm{Ne}-\mathrm{No}$ & 71 & 19.9 & 29 & 8.1 \\
\hline Koristite usluge & $\mathrm{Da}-\mathrm{Yes}$ & 81 & 28.6 & 14 & 4.9 \\
\hline $\begin{array}{l}\text { fSS-Using } \\
\text { forest services }\end{array}$ & $\mathrm{Ne}-\mathrm{No}$ & 33 & 16.8 & 18 & 9.1 \\
\hline
\end{tabular}

moposjednika iz Varaždinske i Međimurske županije (tablica 3), šumoposjednika koji su šumoposjed stekli nasljeđivanjem, koji nisu zainteresirani za gospodarenje, nisu članovi udruga, upisani u upisnik niti koriste usluge Šumarske savjetodavne službe (tablica 4).

Ako usporedimo rezultate $\mathrm{u}$ tablicama 1 i 2 s rezultatima $\mathrm{u}$ tablicama 3 i 4, vidimo da je udio onih koji su jako zainteresirani za kupnju, a nezainteresirani za prodaju šumoposjeda $(23,6)$ za $11,6 \%$ manji od udjela onih koji su jako zainteresirani za kupnju $(35,2)$. Navedeno je posebno izraženo kod šumoposjednika koji su posjed stekli povratom odnosno kupnjom, nezaposlenih, najmlađih šumoposjednika te šumoposjednika koji posjed imaju u Sisačko-moslavačkoj županiji. Najmanja razlika je kod šumoposjednika koji imaju šumoposjed u Varaždinskoj županiji (2,7\%). S druge strane postotak onih koji su nezainteresirani za kupnju, a jako su zainteresirani za prodaju $(7,0)$ je za $11,9 \%$ manji od postotka onih koji su zainteresirani za prodaju $(18,9)$. Među šumoposjednicima Varaždinske županije nema razlike.

Izraženiji interes za povećanjem šumoposjeda (žele kupiti, ne žele prodati) iskazali su: muškarci, mlađi šumoposjednici, više stručne spreme, samozaposleni, koji imaju šumoposjed na prostoru Bjelovarsko bilogorske, Međimurske ili Varaždinske županije, koji imaju posjed između 5 i 50 ha, 
koji su posjed stekli kupnjom, jako su zainteresirani za gospodarenje (tablice 3 i 4 - kolona $\mathrm{n} 1 / \mathrm{n}$, \%). Izraženiji interes za smanjenjem šumoposjeda (ne žele kupiti, žele prodati) iskazali su: žene, stariji šumoposjednici, umirovljenici, šumoposjednici koji imaju šumoposjed na prostoru Varaždinske županije, šumoposjednici koji imaju posjed veličine 20-50 ha, koji su šumoposjed stekli povratom, nisu zainteresirani za gospodarenje (tablice 3 i 4 - kolona $\mathrm{n} 2 / \mathrm{n}, \%)$.

Od šumoposjednika koji su posjed stekli povratom, samo jedan šumoposjednik $(7,7 \%)$ zainteresiran je za povećanje posjeda. U isto vrijeme samo 3 šumoposjednika $(3,2 \%)$ od onih koji su posjed stekli kupnjom voljni su isti prodati, a da pri tome nemaju namjeru kupiti neki drugi šumoposjed (tablica 3).

\section{RASPRAVA}

\section{DISCUSSION}

Dobivena sociodemografska struktura ispitanika (dob, spol, obrazovanje) odgovara do sada provedenim istraživanjima populacije privatnih šumoposjednika (Čavlović, 2004; Posavec i dr. 2015, Curman i dr. 2016., Teslak i dr., 2018). što ukazuje na reprezentativnost uzorka i vjerodostojnost dobivenih rezultata. Udio šumoposjeda manjih od 1 ha u ovom istraživanju je znatno manji $(32,2 \%)$ nego u drugim istraživanjima ili podacima Ministarstva poljoprivrede $(85,2 \%)$, što ipak nije neobično s obzirom na način odabira uzorka i provođenja ankete.

Rezultati rada ukazuju na regionalne razlike u stavovima šumoposjednika prema okrupnjavanju šumoposjeda. Ako promotrimo stupanj zainteresiranosti za npr. kupnju susjednih čestica, najzainteresiraniji za kupnju su ispitanici iz Bjelovarsko-bilogorske županije, muškarci, mlađi, koji su samozaposleni ili nezaposleni te oni koji su jako zainteresirani za gospodarenje. Suuriniemi i dr. (2012) isto tako potencijal za proširenje šumoposjeda vide kod muškaraca i mlađih šumoposjednika, kao i šumoposjednika koji rade u sektoru šumarstva te imaju izrađene planove za gospodarenje. Najnezainteresiraniji za kupnju su ispitanici iz Primorsko-goranske županije, žene, stariji, umirovljenici ili zaposleni te oni koji nisu nimalo zainteresirani za gospodarenje svojom šumom.

Veća zainteresiranost mlađih šumoposjednika za kupnju šume, ali i gospodarenje njome temelj je za promišljanje o poticanju starijih šumoposjednika da šumoposjed prenesu na mlađe članove obitelji (uz uvjet da su mlađi članovi zainteresirani) u nenasljednom postupku, dakle darivanjem istog za svog života ili da prodaju šumoposjed.

Stupanj zainteresiranosti za kupnju susjednih čestica (Kupnja) povećava se povećanjem površine šumoposjeda do kategorije 5-20 ha (tablica 1). Upravo tu površinu (5-20 ha) navodi Schurr (2006) kao minimalnu za samostalno funkcioniranje šumoposjeda.

Veća zainteresiranost samozaposlenih i nezaposlenih za kupnju, vjerojatno je potaknuta željom da povećanjem šumoposjeda poboljšaju svoje financijske prilike. Pri tome je upitno kojim bi sredstvima financirali kupnju šume, što otvara pravac kojim bi trebala ići potpora državnih institucija. Nezaposleni kroz gospodarenje šumom mogu ostvariti zaposlenje, a samozaposleni radom $u$ šumi vide mogućnost „dodatnih prihoda“ $u$ vremenu kada nemaju previše angažmana u temeljnoj djelatnosti (npr. poljoprivrednici zimi) te disperziji djelatnosti u cilju kontinuiranijih prihoda. Većina šumoposjednika slabijeg je imovinskog statusa (Žunić, 2018) te je sukladno tome opravdano da na svoju šumu gledaju kao potencijalni izvor dodatnog prihoda, a uzimajući u obzir gospodarsko, socijalno i demografsko stanje u Hrvatskoj.

Nakon umirovljenika najmanje zainteresirani za okrupnjavanje šumoposjeda kroz kupnju susjednih čestica su zaposleni. To je na neki način razumljivo, jer oni financijska sredstva potrebna za život ostvaruju kroz dohodak od zaposlenja te eventualni prihod od šume ne vide kao nekakav potencijal za poboljšanje životnog standarda, posebno uz činjenice da bi kupnju šume plaćali iz postojećih prihoda ili (nepovoljnih) kredita. Financijski relativno osigurani šumoposjednici svoj šumoposjed doživljavaju kao siguran oblik štednje odnosno ulaganje u budućnost, te u pravilu naglašavaju ekološke funkcije šumoposjeda (Žunić i Teslak, 2019).

Logično je i da se stupanj zainteresiranosti za kupnju susjednih čestica (Kupnja) posebno jako povećava povećanjem stupnja zainteresiranosti za gospodarenje šumom (tablica 2). I prema drugim istraživanjima (Suuriniemi i dr., 2012), mlađi šumoposjednici cijene ekonomske vrijednosti vlasništva i aktivni su na svojim šumoposjedima te će vrlo vjerojatno htjeti proširiti svoje šumoposjede.

Veći stupanj zainteresiranosti za kupnju čestica očekivano je puno veći kod ispitanika koji su šumu kupili (tablica 2). To je i razumljivo, jer oni su svoju zainteresiranost za kupnju već demonstrirali, a ovi rezultati ukazuju da su voljni i nadalje kupovati, odnosno povećavati svoj šumoposjed. To je u skladu s rezultatima Suuriniemi i dr. (2012), koji zaključuju da su upravo šumoposjednici koji su šumoposjed kupili na otvorenom tržištu oni koji će najvjerojatnije proširiti svoje vlasništvo.

Za okrupnjavanje zainteresirani šumoposjednici svoj posjed bi proširili ponajprije kroz kupnju dodirnih (susjednih) čestica. Manji stupanj zainteresiranosti za kupnju čestica koje nisu susjedne (Kupnja 2) očekivano je niži od stupnja zainteresiranosti za kupnju susjednih čestica (Kupnja) kod svih kategorija ispitanika, osim kod šumoposjednika s posjedom veličine 20 i više ha koji su jednako zainteresirani za kupnju, bez obzira jesu li čestice susjedne ili ne. 
Osim kupnjom, okrupnjavanje šumoposjeda se može unaprijediti i zamjenom čestica. Zamjena čestica svojstvena je u širim (regionalnim) i sveobuhvatnim projektima sređivanja pravnog i prostornog stanja zemljišta najčešće pokrenuta od strane javne uprave. Pojedinačne inicijative rijetke su zbog kompleksnog ujednačavanja vrijednosti pojedinih čestica. Iz uzorka kao najzainteresiraniji za zamjenu čestica izdvojili su se nezaposleni i samozaposleni šumoposjednici. Njihovu najveću zainteresiranost za zamjenu čestica pokušali smo dovesti u vezu sa udaljenosti njihovog šumoposjeda od mjesta prebivališta. Međutim kako udaljenost nije promatrana za svaku česticu nego kao prosjek za posjed, nije istražena njihova međuovisnost. Pretpostavljamo da je udaljenost između lokacije šumoposjeda i prebivališta šumoposjednika isto tako razlogom većeg stupnja zainteresiranosti za zamjenu čestica nego za kupnju susjednih čestica kod ispitanika koji su šumu dobili povratom, jer su se od vremena gubitka vlasništva udaljili od šumoposjeda i gospodarenja njime.

Za okrupnjavanje šumoposjeda odlučujuća je i raspoloživost čestica pod šumom na tržištu za prodaju. Jaku zainteresiranost za prodaju iskazalo je samo $18,9 \%$ ispitanika, što je ipak dosta više nego u istraživanjima Žunić (2018), gdje je za prodaju (kategorije „svakako da“ $i$ „vjerojatno da“) zainteresirano svega 7,7\% ispitanika, odnosno sličnom istraživanju za područje Njemačke savezne države Mecklenburg Vorpommern (Schröder i dr., 2008) gdje je iznosila 11\%. Kao razloge niske zainteresiranosti za prodaju šumoposjeda smatramo stavove šumoposjednika koji prema rezultatima Žunić (2018) šumu doživljavaju kao obiteljsko nasljeđe; žele očuvati šumarsku tradiciju obitelji ili kraja te promatraju šumu kao izvor sigurnosti u iznimnim i neočekivanim situacijama. Činjenice da šumoposjednici u najvećoj mjeri nasljeđuju šumu u obitelji i iz tog razloga je ne žele prodati kao ni udruživati se s drugim šumoposjednicima radi gospodarenja, upućuju na duboku emocionalnu povezanost šumoposjednika sa šumom (Glück i dr., 2010).

Rezultati ukazuju i na malu i statistički neznačajnu korelaciju između stupnja zainteresiranosti za kupnju i prodaju što vidimo kao jedan od većih problema u postupku okrupnjavanja. Ona je posljedica prije svega male zainteresiranosti šumoposjednika za prodaju (tablica 2). Za okrupnjavanje šumskih površina idealno bi bilo da je ta korelacija negativna, visoka i statistički značajna. Međutim, iz dobivenih rezultata slijedi da oni koji su zainteresirani za kupnju, u biti nemaju od koga tu šumu kupiti, jer je zainteresiranost za prodaju šumoposjeda dosta niža u odnosu na zainteresiranost za kupnju (tablica 2). Slaba zainteresiranost za prodaju šuma u skladu je s rezultatima ankete provedene na području Zagrebačke županije, gdje čak $65 \%$ privatnih šumovlasnika nije bilo spremno prodati svoj sitni šumoposjed (Čavlović, 2004). Da bi pojedini šumoposjednik mogao povećati svoj šumoposjed moraju postojati drugi šumoposjednici koji su voljni prodati šumoposjed koji je potencijalnim kupcima zanimljiv s obzirom na prostor na kojemu se nalazi, kvalitetu šumoposjeda i traženu cijenu. Niska, pozitivna i statistički neznačajna korelacija između kupnje i prodaje $(0,07)$ svakako ograničava mogućnost povećanja šumoposjeda. Iako je jako zainteresiranih za kupnju bilo $35,2 \%$ ispitanika (tablica 1), povećanje šumoposjeda mogli bismo očekivati od njih 23,6\% (tablica 3). To su oni koji su jako zainteresirani za kupnju, a nezainteresirani za prodaju šumoposjeda. Većinom su to: muškarci, mlađi, obrazovaniji, samozaposleni ili nezaposleni, iz Bjelovarskobilogorske županije, s većim posjedom, koji su posjed stekli kupnjom, članovi su neke od udruga šumoposjednika te su upisani u Upisnik.

Osim nedovoljne ponude šumskih čestica na tržištu problem za okrupnjavanje predstavlja i formiranje cijene za iste. Realna vrijednost pojedinog šumoposjeda između ostalog ovisi o njegovoj veličini, položaju, prostornoj homogenosti, mogućnosti identifikacije u prostoru, pristupu prometnicama, vrstama drveća, omjeru smjese, uzgojnom obliku, kakvoći i dimenzijama stabala. Vrijednost šumskog posjeda ovisi i o financijskom učinku koji se iz njega može polučiti u određenom intervalu vremena. Prema Schurru (2006) gotovo svaka čestica je jedinstvena, sa svojom kombinacijom tla i šume koja na njemu raste koji određuju njenu vrijednost. Međutim u konačnici šumoposjed na tržištu vrijedi onoliko koliko je netko za njega spreman platiti.

Održivo gospodarenje moguće je jedino na većim šumoposjedima, a šumoposjednici nisu u mogućnosti gospodariti svojim posjedima bez podrške javnih institucija za šumarstvo zbog nedostatka osposobljenosti i edukacije (Glück i dr., 2010). Ograničenja u gospodarenju šumama koja proizlaze iz veličine šumoposjeda prepoznata su i u Hrvatskoj (Posavec i dr., 2011; Teslak i dr., 2018; Žunić i Teslak, 2019). Prema Glücku i dr. (2010) šumoposjednici čiji su posjedi manji od 1 ha doživljavaju svoje šume više kao problem, a ne kao priliku te bi se njih trebalo poticati na prodaju šumoposjeda. Međutim, značajan broj šumoposjednika svoj mali šumoposjed (općenito posjedovanje nekretnina) smatra najsigurnijim ulaganjem, čime je proces okrupnjavanja šumoposjeda dodatno otežan. Upravo zato da bi se povećala gospodarska aktivnost na postojećim šumoposjedima i potaknula prodaja odnosno kupnja čestica pod šumom, potrebna je značajnija državna potpora kroz dizajniranje i donošenje učinkovitih mjera te angažman struke vezano uz edukaciju šumoposjednika.

Najveći broj šumoposjednika u Hrvatskoj posjed je stekao nasljeđivanjem. Prema Zakonu o nasljeđivanju u RH (NN 48/2003) ne postoje restrikcije prilikom nasljeđivanja šumskog zemljišta u smislu minimalne veličine koja se može dalje dijeliti u procesu nasljeđivanja, što dovodi do parce- 
lizacije i nastanka površinski malih posjeda (Krajter Ostoić i dr., 2015; Žunić, 2018). Stoga bi reguliranje nasljednog prava bilo poželjna mjera u cilju ograničavanja dodatne parcelizacije odnosno smanjenja površine šumoposjeda, za što svakako mora postojati politička odluka, kao u primjerima Finske i Austrije (Suuriniemi i dr., 2012; Schmithüsen i Hirsch, 2010).

Uloga državnih institucija u povećanju zainteresiranosti šumoposjednika za prodaju može biti kroz poticanje šumoposjednika s malim i raštrkanim posjedima za njihovu prodaju. Pri tome predlažemo primjenu "germanskog koncepta vlasništva" koji se temelji na tvrdnji da nema prava bez obveza (Depenheuer, 2000, prema Schurru, 2006). Mjere oporezivanja i penaliziranje negospodarenja šumoposjedom te subvencioniranje troškova rješavanja vlasničko-pravnog statusa, ali i samog prihoda od prodaje, također su mogući pravci djelovanja. Međutim uspjeh mjera nametnutih od strane regulatora gospodarenja šumama ovisan je o širem sagledavanju dugoročne socijalne i pravne sigurnosti u društvu. Buduće okrupnjavanje šumoposjeda (i očekivano bolje gospodarenje njima) ovisi o jačanju socijalne i pravne sigurnosti te uspostavi ažuriranog vlasničkog stanja koje moraju pratiti mjere šumarske politike. Bitan preduvjet za to je usklađivanje vlasničkih knjiga i stvarnog stanja (katastra) zemljišta na razini cijele države. Neke od specifičnih mjera koje bi se mogle poduzeti/propisati jesu: isplata dodatka na mirovinu šumovlasnicima koji su spremni prodati ili otpisati svoju šumu, s obzirom da umirovljenici čine značajan udjel $(39,8 \%)$ šumoposjednika u Hrvatskoj s pretežno malim mirovinama, ili naprotiv uvođenje poreza na šumu i šumsko zemljište u slučajevima izostanka aktivnog gospodarenja šumama. Sličan utjecaj na šumoposjednike moguć je i posredno kroz penaliziranje pojave šumskih štetnika, korovskih vrsta, alohtonih vrsta i slično.

Otežavajuća okolnost povećanju zainteresiranosti za kupnju čestica pod šumom i aktivno gospodarenje šumom očituje se u sve većim ograničenjima vezano za zaštitu prirode (npr. Natura 2000 područja), na što predstavnici šumoposjednika opetovano ukazuju. Upravo zbog ograničenja iz propisa o zaštiti prirode, neki od šumoposjednika „boje se“ gospodariti svojom šumom (Schurr, 2008), a slično se može očekivati i u Hrvatskoj s obzirom da je većina površine šuma pod nekim oblikom zaštite. Slaba zainteresiranost za gospodarenje šumom, a time i kupnju šuma u RH razumljiva je također zbog niske razine imovinskih prava šumoposjednika u RH u usporedbi s drugim europskim državama (Nichiforel i dr., 2018). U prilog okrupnjavanju šumoposjeda ne ide ni najavljena politika ograničavanja količine etata (sječivog volumena) vezano za emisije ugljičnog dioksida. Posebno je to važno za sitne, privatne šumosposjede koji većinu posječenog drva plasiraju kao biomasu ili ogrjevno drvo što će se posebno destimulirati. Uz izvje- stan nestanak tržišta za tradicionalne proizvode privatnih šumoposjeda (npr. ogrjevno drvo) već sad je potrebno poticati preorijentaciju šumoposjednika na nedrvne šumske proizvode. Pri tome regulator mora predvidjeti obeštećenja šumoposjednika za izostalo gospodarenja šumama i njima prepustiti lovno gospodarenje, regulirati branje gljiva, šumskih plodova i ostalih nedrvnih proizvoda te osigurati naknadu za općekorisne funkcije šuma.

Iz svega navedenog vidljivo je da značajan dio šumoposjednika neće moći samostalno pratiti sve izazove koje ih očekuju u budućem gospodarenju svojim često premalim šumoposjedom, stoga je iznimno važno jačati ulogu javnog servisa u vidu državne agencije za šume u RH. Agencija za šume mora postati nositelj: a) prikupljanja, čuvanja i korištenja svih podataka o šumama, b) koordinator donošenja svih pravnih i drugih dokumenata o šumama, c) donositelj planova gospodarenja šumama na svim razinama, d) jamac dosljedne provedbe prihvaćenih planova gospodarenja. Samo uspostava javnog servisa koji ima navedena obilježja te bi bio nadležan za sve šume (uključujući i privatne), uz sveukupnu socijalnu i pravnu sigurnost $\mathrm{u}$ društvu, omogućava daljnji razvoj gospodarenja privatnim šumama, u čemu je značajan čimbenik mogućnost njihova okrupnjavanja.

\section{ZAKLJUČAK CONCLUSION}

U Republici Hrvatskoj prevladavaju mali šumoposjedi veličine do 1 ha, a svega $0,28 \%$ šumoposjednika ima posjed veći od 10 ha. Ako za granicu smislenog gospodarenja šumoposjedom podrazumijevamo površinu posjeda od 10 ha vidljivo je da veličina šumoposjeda predstavlja ograničavajući čimbenik daljnjeg razvoja privatnog šumarstva u Hrvatskoj. Prema tome okrupnjavanje šumoposjeda i smanjenje broja šumoposjednika nameće se kao temeljni cilj daljnje politike reguliranja privatnog šumarstva. Povećati posjed moguće je kupnjom susjednih ili ne-susjednih čestica, a povećati suvislost šumoposjeda i zamjenom čestica. Paralelno trebaju postojati šumoposjednici voljni odustati od svog posjeda odnosno prodati šumu u korist onih koji žele okrupniti šumoposjed.

Prema rezultatima tipičan šumoposjednik zainteresiran za okrupnjavanje šumoposjeda je mlađi obrazovaniji muškarac iz središnje Hrvatske, koju je svoju šumu stekao kupnjom i već je aktivan u gospodarenju šumama bilo kroz članstvo u udrugama bilo kroz savjetodavne aktivnosti Ministarstva poljoprivrede. Za kupnju su zainteresiraniji nezaposleni i samozaposleni, čime vide mogućnost samozapošljavanja i povećanja prihoda. Značajan broj šumoposjednika je potpuno neaktivan i nisu zainteresirani za promjenu statusa svog šumoposjeda. Među neaktivnim, starijim, manje obrazovanim šumoposjednicima s manjom površinom 
šumoposjeda premali je broj zainteresiranih za prodaju svog neperspektivnog šumoposjeda, što onemogućava povećanje prosječnog šumoposjeda u Hrvatskoj. Većina tih šumoposjednika svoj posjed vidi kao sigurnu imovinu kojoj će vrijednost rasti, a trenutno nisu zainteresirani provesti postupak prodaje. U tim okolnostima daljnjem usitnjavanju šumoposjeda dodatno doprinosi važeći proces nasljeđivanja.

Navedeni rezultati istraživanja povezanosti obilježja šumoposjednika s njihovim aktivnostima u procesu kupo-prodaje čestica pod šumom trebali bi biti temelj oblikovanja mjera šumarske politike vezano za privatne šume. Nažalost, u bitnim odrednicama šumarska politika je unaprijed određena širim sagledavanjem politika povećanja površina pod sve strožom zaštitom te ograničenjima vezanim za emisije ugljika koje destimuliraju aktivnosti šumoposjednika na jačanju privatnog šumarstva, za čiji je razvoj neophodno jasno imovinsko-pravno stanje te okrupnjavanje i povećanja površine šumoposjeda.

Unatoč neizvjesnom budućem okviru gospodarenja šumama daljnje mjere šumarske politike treba usmjeriti na poticanje aktivnog i disperziranog gospodarenja šumama (biomasa, nedrvni šumski proizvodi, općekorisne funkcije šuma, naknade za ponor ugljika, naknade za ciljane vrste) uz poticanje prodaje, zamjene ili ustupanja površinom neperspektivnih šumoposjeda te penaliziranje izostanka gospodarenja šumoposjedom.

\section{ZAHVALA ACKNOWLEDGEMENTS}

Istraživanje je provedeno u sklopu projekta: “Okrupnjavanje šumoposjeda i udruživanje šumoposjednika kao pretpostavka održivog i učinkovitog gospodarenja sitnim privatnim šumama" koje je financiralo Ministarstvo poljoprivrede. Zahvaljujemo djelatnicima Ministarstva poljoprivrede i Hrvatske poljoprivredno-šumarske savjetodavne službe na pomoći pri provedbi istraživanja.

\section{LITERATURA}

\section{REFERENCES}

- Berta, A., V. Kušan, J. Križan, D. Stojsavljević, D. Hatić, 2017: Posjedovne i površinske značajke šuma šumoposjednika u Hrvatskoj prema regijama. Šumarski list 141(1-2): 57- 64.

- Božić, M., 2011: Istraživanje i izrada modela uređivanja i izmjere šuma u šumama šumoposjednika. Šumarski fakultet, Završno izvješće za projekt, Zagreb 188 str.

- Butler, B., Caputo, J., Robillard, A.L., Sass, E.M., Sutherland, C., 2021: One Size Does Not Fit All: Relationships between Size of Family Forest Holdings and Owner Attitudes and Behaviors. Journal of Forestry,119 (1): 28-44.

- Curman, M., S. Posavec, Š. Pezdevšek Malovrh, 2016: Willingness of Private Forest Owners to Supply Woody Biomass in Croatia. Small-Scale Forestry 15(4): 551-567.
- Čavlović, J., G. Pelzmann, 2003: Small scale forests and small scale forest owners in Croatia. Rural development strategy for Croatia, FAO, Rome, Italy. 29 str.

- Čavlović J., 2004: Unapređenje stanja i gospodarenja privatnim šumama na području Zagrebačke županije (znanstvena studija). Šumarski fakultet Sveučilišta u Zagrebu, Zagreb

- Ficko, A., A. Boncina, 2015: Forest owner representation of forest management and perception of resource efficiency: a structural equation modeling study. Ecology and Society 20(1): 36.

- Glück, P., Avdibegović, M., Čabaravdić, M., Nonić, D., Petrović, N., Posavec, S., Stojanovska, M. 2010: The Preconditions for the Formation of Private Forest Owners' Interest Associations in the Western Balkan Region. Forest Policy and Economics, 12 (4): 250-263.

- Krajter Ostoić, S., Posavec, S., Paladinić, E., Županić, M., Beljan, K., Curman, M., Ćaleta, M., Šimunović, N. 2015: Forest Land Ownership Change in Croatia. COST Action FP1201 FACESMAP Country Report, European Forest Institute Central-East and South-East European Regional Office, Vienna. 40 pages. Online publication.

- Nichiforel,L., Keary, K., Deuffic, P., Weiss, G., Jellesmark Thorsen, B.,Winkel, G., Avdibegović, M., Dobšinská, Z., Feliciano, D., Gatto, P.,Gorriz Mifsud, E., Hoogstra-Klein, M., Hrib, M., Hujala, T., Jager, L., Jarský, V., Jodłowski, K., Lawrence, A., Lukmine, D., Pezdevšek Malovrh, Š., Nedeljković, J., Nonić, D., Krajter Ostoić, S., Pukall, K., Rondeux, J., Samara, T., Sarvašová, Z., Scriban, R.E., Šilingienè, R., Sinko, M., Stojanovska, M., Stojanovski, V., Stoyanov, N., Teder, M., Vennesland, B., Vilkriste, L., Wilhelmsson, E., Wilkes-Allemann, J., Bouriaud, L., 2018: How private are Europe's private forests? A comparative property rights analysis. Land Use Policy, 76: 535-552.

- Paladinić, E., D. Vuletić, S. Posavec, 2008: Pregled stanja privatnog šumoposjeda u Republici Hrvatskoj. Rad. - šumar. inst. Jastrebar. 43(1): 45-58.

- Posavec, S., Trninić, S., Čavlović, J., 2006: Current status and trends in private forests of Croatia, in: W. Sarah (Ed.), Smallscale Forestry and Rural Development the Intersection of Ecosystems, Economics and Society, COFORD, Galway, Ireland, 409-415.

- Posavec, S., M. Šašek, K. Beljan, 2011: The structure and potential of small scale forests in the north-west of Croatia. U: Hartebrodt, C., K. Howard (ur.): 2011 IUFRO Small-Scale Forestry Conference, Freiburg. Fakultät für Forst- und Umweltwissenschaften der Universität Freiburg Forstliche Versuchs- und Forschungsanstalt Baden-Württemberg (FVA), Freiburg. str. 107- 112

- Posavec, S., K. Beljan, 2012: Information analysis of management goals of private forest owners in Croatia. Informatol 45(3): 238-245.

- Posavec, S., M. Avdibegović, Dž. Bećirović, N. Petrović, M. Stojanovska, D. Marčeta, Š. Pezdevšek Malovrh, 2015: Private forest owners' willingness to supply woody biomass in selected South-Eastern European countries. Biomass and Bioenergy (81): 144-153

- Schmithüsen, F., Hirsch, F. 2010: Private forest ownership in Europe. Geneva Timber and Forest Study Paper 26. UNECE/ FAO. Geneva, Switzerland.

- Schröder, J., Lindenkreuz, K., Illing, R., 2008: Nachhaltige Ressourcennutzung im Kleinprivatwald: Projektstudie im Forschungsverbund Holz Cluster Nord. Schwerin: Ministerium 
für Landwirtschaft Umwelt und Verbraucherschutz Mecklenburg-Vorpommern. 69 str.

- Schurr, C., 2006: Zwischen Allmende und Anti-Allmende. Dissertation, Albert-Ludwigs-Universität Freiburg im Breisgau, Fakultät für Forst- und Umweltwissenschaften, 638 str., Freiburg im Breisgau.

- Suuriniemi, I., Matero, J., Hänninen, H., Uusivuori, J. 2012: Factors affecting enlargement of family forest holdings. Silva Fennica, 46 (2): 253-266.

- ŠGOP, 2016 - Šumskogospodarska osnova Republike Hrvatske za razdoblje 2016. - 2025., Zagreb.

- Teslak, K., Žunić, M., Beljan, K., Čavlović, J., 2018: Stanje i izazovi gospodarenja privatnim šumama u Hrvatskoj u postojećim ekološkim i sociološkim okolnostima. Šumarski list, 142 (9-10): 459-471.

- TIBCO Software Inc., 2018: Statistica (data analysis software system), version 13. http://tibco.com.

- Zakon o nasljeđivanju. Narodne novine 48/2003.

- Zakon o šumama. Narodne novine 68/2018.

- Žunić, M., 2018: Modeli gospodarenja privatnim šumama u Republici Hrvatskoj s obzirom na stavove šumoposjednika i obilježja šumoposjeda. Doktorski rad. 164 str. Šumarski fakultet Sveučilišta u Zagrebu. Zagreb

- Žunić, M., Teslak, K., 2019: Ograničavajući čimbenici izostanka aktivnosti na šumoposjedima u Republici Hrvatskoj - MIMIC model. Šumarski list, 143 (1-2): 7-17.

\section{SUMIMARY}

Most forest owners in Croatia have forest holdings smaller than 1 ha, while less than $1 \%$ have holdings larger than 10 ha. Parcelization of forest holdings in addition to small size presents significant limitation for forest management. Therefore, important aim of forest policy is to stimulate enlargement and consolidation of forest holdings. First step in that process is to recognize the characteristics of forest owners interested in enlargement of their holdings and active forest management.

The aim of this research is to relate the sociodemographic attributes of private forest owners and characteristics of their forest holdings with their interest for selling and/or buying forest estates for enlargement and consolidation of forestland area.

Direct survey questionnaire covered 500 private forest owners in continental part of Croatia. Respondents are classified by sex, education, employment, location of forest holding, activities in forest associations and means of acquisition of forest estate. Answers included level of interest for activities in enlargement and management of forest holdings. Statistical analysis included descriptive statistics (arithmetic mean, median, and standard error), testing between groups (Mann Whitney and Kruskal Wallis test), and Spearman rank correlation.

The results indicate correlation of sociodemographic, regional and other characteristics of forest owners with their interest in enlargement of forest holding. According to these results most interested in enlargement of forest holding are younger male owners from the central Croatia who purchased forest and are already active in forest associations (tables 1 and 2). Non-employed and self-employed owners are also more interested in enlargement of forest area to increase their incomes (table 1). However significant share of owners (35\%) are not interested in increase nor in selling their forest (Figure 1 ) which is an impediment in consolidation of forest areas.

The results of this study are useful for future forest policies aimed at small scale forestry, although these actions are subject to large scale restrictions due to increase of protected areas and limitations to forest management resulting from reducing carbon emissions. Therefore, state regulatory measures should aim at subsidizing active and diversified forest management (forest biomass, non-wood forest products, amenity values, credits for carbon sequestration, aimed species, biodiversity). On the other hand, law measures should improve the process of inheritance and penalize the abandonment of forest areas (sources of pests and diseases, invasive species, forest fires).

KEY WORDS: private forests, purchase and selling of forest area, forest management, consolidation 